\title{
Alevis' Perspective on the Kurdish Movement and the Establishment of Distance
}

\author{
Hülya Doğan \\ Anthropologist, Turkey
}

\begin{abstract}
Kurds and Alevis have been two major ethnic groups that have fought for equal citizenship rights since the foundation of the Turkish Republic. However, in the historical process, both the influence of the dominant state discourse, the conflicts created by the global powers and the codes that settle in the historical-cultural memories keep a tension line alive between these two groups. Comprehending this tension requires understanding all these processes and various reactions. For example, migratory movements caused by the war in Syria lead to the rise of nationalism in Turkey, and the Kurds and Alevis, therefore, found themselves on different fronts. Or Alevis can believe the government's nationalist discourse when it is about connecting HDP with terrorism although they do not agree with AKP (leading party of the government) under any other circumstances. This study intends to go deep into this tension, which can only be understood by making contact with the world of mentality, through field research which is the method of anthropology. In order to end the polarization which is fed by the hatred of identities and to establish a real democracy can only be made possible by the egalitarian contact of the oppressed peoples. Especially in a time where the authoritarian regimes are rising all over the world. For this reason, the study focuses on deciphering the interaction of the Alevis with the nationalist discourse that causes this hatred and finding the possibilities of establishing peaceful ways of communication.
\end{abstract}

Keywords: Alevism; nationalism; Kurdish movement; Turkey; identity

\section{Introduction}

The AKP (Justice and Development Party) government in Turkey is one of the examples of rising authoritarianism in the world. Since 2002, the AKP has been in power with conservative Islamist and capitalist policies. Finally, as a result of a referendum held in 2017 in Turkey, the country has adopted the Presidential System, where the president is also a member of a political party. The AKP demonstrates almost an example of dictatorship, with its discourse that promotes and legitimizes discrimination, keeps the images of internal and external enemies alive, and gathers all authority in one person. Sözen (2011: 8) defines AKP's ideology as "neoconservative populism" and lists the elements of this ideology as neoliberalism, conservatism, and populism. Their ideas are based on a Sunni-Turk nation thought which is independent of classes. The authoritarian regime of the AKP attacks all democratic rights and institutions that 
pursue these deep-rooted rights. Following a failed coup attempt by a congregational group on 15 July 2016, the President of the AKP and the President of Turkey R. T. Erdoğan, who declared the state of emergency indefinitely, said in a meeting organized by the International Investors Association (Uluslararası Yatırımcilar Derneği) in the first year of the state of emergency: "In case of threat of strikes, we respond immediately by making use of the state of emergency. We say no we don't allow a strike here, because you can't shake our business. We use it for this." 1 First actions realized with the Decree Laws issued on the occasion of the state of emergency were to expel critical academics, unionized teachers, arrest journalists and important political figures, and close down non-governmental organizations and dissident media channels. As this situation shows, the AKP regime defines democratic rights as an attack on the interests of the country and does not refrain from accusing the opposition with treason. He patches up the places left by his Islamist fabric, especially after his alliance with the MHP, with nationalism and establishes his hostile rhetoric. In this context, the HDP (Peoples' Democratic Party), which places the demands of democracy and equal citizenship at the center of its discourse, is being antagonized by the AKP. The treatment of the HDP as a terrorist organization becomes possible through the redefinition of the Kurdish Question. The AKP perceives the attempts of local governments, which are tried by HDP municipalities at home, and the efforts of Syrian Kurds abroad, as threats. In this context, it cooperated with the imperialist powers to take advantage of the conflict in Syria and ended the so-called "solution process". ${ }^{2}$ The AKP has placed nationalism at the center of the dominant discourse. The AKP regime is one of the best examples of how nationalism and political Islam constituent authoritarian and capitalist regimes.

The possibilities of opposition are also limited in an environment of intense repression. Labor unions have to deal with the cases of unjustly expelled members and executives who are repeatedly detained. Rights such as organizing a protest march, which has a very basic and constitutional basis, cannot be exercised. Opposition parties, which have the opportunity to represent in parliament, are working despite the proceedings and the arrests which do not recognize the chair immunity. Even the HDP deputies' demands for pending trial remain unanswered. However, these parties cannot unite their agendas against the authoritarian AKP regime. The fact that the main opposition party, the CHP (Republican People's Party), acts jointly with the Iyi Party established by the nationalists leaving the MHP weakens the hand of class opposition. On the other hand, the CHP increases its distance from the Kurds and divides the opposition although HDP supported their coalition at the last election.

At this point, understanding how an authoritarian regime divides its opponents by nationalist discourse gets more important. This work questions the establishment of the distance between two major opposing groups against dictatorship in Turkey from the side of Alevis. It contents not only an ongoing fieldwork with Alevis from central Anatolia region (the majority of Alevis)

\footnotetext{
1 "Emergency State came under the pretext of strike, should be removed", 13 July 2017, http://disk.org.tr/2017/07/ohalgrev-yasaklama-bahanesi-haline-gelmistir-kaldirilmalidir/, cited date 19.07.2019.

${ }^{2}$ The Solution Process is the name of the process in which the AKP declared that it decided to solve the Kurdish Question through peace, which was later understood to have begun in 2009 with the meeting between the PKK and the MIT in Oslo. PKK leader Abdullah Öcalan, the parliamentary representative of the Kurdish opposition BDP (which was shut down in 2014 and continues to politics as HDP) and the PKK executives in Kandil were included in the meetings, and deputies and government representatives made a joint statement in Dolmabahçe Palace. It is the process that ended with the rejection of the text of the agreement (which mentions about changes such as equal citizenship, self-government model and the strengthening of civil society) by President Erdoğan.
} 
who live in Ankara, but also observations of an anthropologist who lives with them for long years.

\section{Alevism as an Opposing Ethno-Religious Identity}

Within this repressive environment, one of the prominent secular groups that have resisted (although generally not in action) the AKP administration since the first day of its rule is the Alevis who have not lost their loyalty to the achievements of the Turkish Republic and its founding ideology. The concept of "Alevism" is used to describe those who took the side of the prophet's cousin Ali during the uncertainty about the identity of the caliphate after the death of the prophet Muhammad. In Arabic, Alevi means "belongs to Ali" or "pro-Ali". However, Alevism has assumed different meanings according to regions and countries in the historical process (Y1lmaz, 2005: 29). In Anatolia, the Alevis, who are called as Qizilbash, belonged to the Turkmen (Turkoman) tribes who were Safavid supporters in the 15th and 16th centuries. This concept has been given the meaning of irreligious / insurgent over the centuries due to religious-social uprising movements such as the Celali Rebellions. As of the 19th century, it is stated that the concept of Alevism began to be used to name a heterodox Islamic sect (Melikoff, 1994).

Although not so during the foundation of the state ${ }^{3}$, the Alevis were marginalized and subjected to discrimination policies when the state religion of the Ottoman Empire became Sunni Islam in a short period of time. Because of their understanding of Islam, their lifestyles and their connections to the Safavids, Alevis were massacred systematically under Ottomans' empery.

With the collapse of the Ottoman Empire, the Republic of Turkey was established on the basis of secularism. In this period, Alevis became an ethnoreligious group that adopted the new state. "The dynamics such as the formation and disruption of history, the emergence of other ethnic groups within itself, its division and becoming inclusive in this context, the ethnicization of clusters which are not an ethnic context in historical conditions or the making of certain religious or cultural characteristics of an ethnic entity as the main source of attachment" (Aydın, 2016: 13) also allows us to see Alevism as an ethnoreligious category.

Discrimination and massacre against Alevis continued after the foundation of the Republic. Within the scope of Dersim Massacre, in 1937, with the decision of the Council of Ministers, not only Alevis, but also thousands of Kurds, Zazas and Armenians were killed or forced to abandon their beliefs and settle alongside Muslim Turks. In 1978, hundreds of Alevi people were brutally murdered in Maraş with their children. In 1980, 57 people were killed as a result of armed attacks in Çorum. In 1993, 33 Alevi intellectuals were burned in Sivas. In 1995, 22 people were killed as a result of armed attacks in the neighborhoods of Gazi. Today, the Alevis, whose doors are still marked in some places, are profoundly uneasy. The perpetrators of these massacres have not been revealed. Lastly, the perpetrators of the Sivas massacre were not punished, and the case was barred by prescription after twenty years had passed. This has fueled

${ }^{3}$ At the beginning of the Ottoman Empire's foundation, mostly Qizilbash leaders were joining wars for expanding Ottoman's territory. When the state's religious character was framed in Sunni Islam officially, oppression on Alevis started to get more strong and violent. To read more about this process, you may look at Rıza Yıldırım (2018), Aleviliğin Doğuşu (The Origins of the Qizilbash Identity in Anatolia), trns: Barış Yıldırım, İstanbul: İletişim, 2. Ed. 
a deep sense of injustice. Moreover, the AKP leader R. Tayyip Erdoğan's celebration of the statute of limitations has irrevocably deepened the gap between the AKP regime and the Alevis.

On the other hand, there is discrimination against Alevis in social and cultural spheres. The djemevis (cemevi), where Alevis perform their rituals and practices of worship, are not recognized by the state and are not considered as legitimate places of worship. This is a serious injustice to the Alevis who could not educate the religious people of their own sects even though they paid the same tax like other citizens. Religion lessons (scripture classes) in which Sunni Islamic philosophy and practice are taught in primary and secondary education are compulsory in Turkey. Mandatory participation in these classes displays that the assimilation policies that Alevis are exposed to continue.

Despite all these problems, Alevis do not give up the basic values of the republic and especially the secularism which they see as a guarantee of their existence. Although it remains passive in expressing the egalitarian demands of the Alevis, they continue to support the CHP which was founded by Atatürk. As a historical figure, Atatürk has a special place for the Alevis. The photo of Atatürk is hung in the djemevis (cemevi) with the picture of Hz. Ali.

"Even if they gave me the whole wealth of the world, even if I knew that I would die; I would never vote for any other party. I know that Atatürk was also an Alevi!" (interview n. 25, woman, 59, retired worker, 18 August 2020)

"There is no political party which represents Alevis but the closer one is the CHP which does honest and right things since my childhood period. But they do not get any benefit from CHP. It is just because Atatürk founded it. Alevis never give up from Atatürk. It is maybe because Atatürk was righteous, honest and a qualified statesman, because his point of view on Islam..." (interview n. 15, man, 52, soldier, 8 March 2020)

Moreover, it is determined that Kurdish Alevis as well as Turkish Alevis support the secular and populist ideas of Kemalism and affiliate / assimilate to Turkish culture (Bruinessen, 2013: 119). Therefore, it is out of the question for Alevis to accept the conservative Islamist rhetoric and freedom-limiting approach of the AKP that intervenes to people's way of life.

"CHP is the closest political party to my opinions, second one is maybe HDP. I can not count the others even. I do not think there are Alevis who vote for AKP or for other Islamic parties. They must be changed" (interview n. 13, woman, 57, retired worker, 26 February 2020).

But Alevis are being forced to vote for AKP for their basic and vital requirements, especially in villages all over the country.

"We never vote for AKP as Alevis from Yozgat. Only in some of the villages they have to give some votes to request for their roads' maintenence and repair, for example. My cousin has been the headman of our village for twenty years. They refuse his requests, saying that there is no vote no work. At the last local election they gave six votes for AKP. They built a very ugly system" (interview n. 34, man, 67, retired public servant, 30 August 2020).

Nevertheless, there are differences between Alevis, especially on the Kurdish issue, due to the long-standing conflict in the country, the high number of deaths and the inexorable propagandistic discourse of the state. 


\section{Kurdish Political Movement}

After describing Alevis as an ethnoreligious identity, it is necessary to briefly mention the history of Kurds who expressed their political and cultural demands in different ways in order to protect their identities and lifestyles since the first period of the Republic. Nationalist ideas, which coincided with the last century of the Ottoman Empire, influenced Anatolia as well. The emergence of the Kurds in a political formation is associated with a newspaper called "Kurdistan", which was published by Mikdat Mithat Bedirhan in 1898 (Ball1, 1992). Turkism was the basic idea during the establishment of the Republic of Turkey. Other identities that have gained political consciousness in this process have been ignored. Kurds constituted the most striking difference in terms of population and political activity in the region within the Misak-ı Milli (National Pact), which was formed during the War of Independence. Prohibition of cultural and political demands of Kurds in order to protect these borders began in the early years of the Republic. Sixteen of the eighteen revolts that took place during this period (19241938) were committed by the Kurds. The discontent of the Kurds has focused on Turkish nationalism, Westernization, centralization, and secularism (Kirişçi, Winrow; 1997). This series of revolts, which ended with the Dersim Massacre, silenced the Kurdish opposition until the 1960s.

The relatively libertarian environment of the 1960s helped the Kurdish opposition reorganize, made theories to be produced that add the opposition of identity to the class struggle, and made possible a period of the emergence of opposition groups which later joined the TIP (Labor Party of Turkey) in the parliament. However, this period was interrupted by military interventions and the participation of the PKK armed organization increased especially as a result of the 1980 coup in which Kurdish dissidents were killed by inhuman torture. During the decades of armed struggle, the Kurds sought ways of political opposition in parliament. A new era of Kurdish political opposition started with the HEP (People's Labor Party) they established in 1990. However, this process of seeking democratic grounds has been almost sabotaged due to the difficulty of overcoming the election threshold, as well as the closure of each party and the arrest of deputies. On the other hand, for the Kurds, the 1990s was a period, under the name of fighting terrorism, in which villages were burned, people were expelled from their homes, people were killed in custody and torture became widespread. Turkey's two major ethnic groups, the Kurds and the Alevis, were continued to be simultaneously marginalized in different ways. While the Sivas massacre, where Alevi intellectuals were burned, was watched live on television screens, it was not possible to be aware of the Kurds' experiences because of the antiterror rhetoric in the media.

After all, the word 'peace' was first pronounced in 2009. As a result of this process, which started under the AKP rule and ended in five years, the actors of the Kurdish side of the process are still being tried in the courts. The former leader of the party, Selahattin Demirtaş, who directly told Erdoğan that they would not let him to be a president and who raised the votes of HDP, is still being kept in prison since 2016 although the opposite decisions of European Court of Human Rights and the government appointed trustees to the most of municipalities belonged to HDP according to the election. Especially Demirtaş, as a figure of oppression in Turkey is 
easily connecting with Alevi subconscious ${ }^{4}$. Most of the participants, especially women, sympathize Selahattin Demirtaş independent of HDP or Kurdish political movements.

"My trust in Kurdish politics depends on the person who leads it. I can trust Demirtas till the end. Kurdish people frighten our community. Extremely religious cults are increasing in them a lot." (interview n. 11, woman, 62, housewife, 18 February 2020).

"Selahattin Demirtaş is a very valuable figure with what he has done, his honesty. We cannot trust Kurdish politicians. Actually, it is not only their fault. They are not able to talk honestly because of government's 'reading intention' activity." (interview n. 21, woman, 52, lawyer, 4 August 2020)

Despite this blatant injustice, Alevis can be affected by the government's terrorism discourse and nationalist propaganda. They may prefer to believe AKP only about Kurdish issue.

"Kurds tried to look out for their benefits, made secret plans but it did not get well. There are some Kurds shaking hand with AKP. During the solution process, HDP asked for excess demand, like autonomy but it was not hold with the government, I guess." (interview n. 12, woman, 38, doctor, 25 February 2020)

\section{Alevis Getting in Touch with Turkish Nationalism}

Much has been said and written about the relationship of ethnic groups with nationalism that is claimed to be identical with the nation. Even nationalism is conceptualized as an ideology that mobilizes these groups. However, it is a peculiar problem that Alevis, as an ethnoreligious identity that has experienced serious grievances at the times when this ideology was strengthened, can be persuaded from time to time by the thesis of Turkish nationalism. Despite their dissenting stance, it is observed that Alevis may be influenced by nationalist discourse, especially in the case of the Kurdish issue. This situation separates the Alevis and Kurds, who struggle for equal citizenship and cultural identity since the foundation of the Turkish Republic, rather than unifying them around common interests. As Zirh (2016) emphasizes, in Turkey, the identities that are pushed beyond the acceptable limits of "national conservatism", which gradually increases its pressure, are the Kurds and the Alevis along with the Armenians. Turkey's becoming an egalitarian democracy depends on achieving peace. The emergence of this demand and its transfer to the political sphere depends on the people who resist the discriminatory and alienating discourses or at least have access to alternative explanations. It is of great importance that Alevis and Kurds approach each other around common issues and establish an egalitarian communication.

The contact of Alevis with Turkish nationalism begins with the first construction of the Turkish nation. For the new nation state's establishment, historians started digging the folk culture of Anatolia before Islam and it was suitable to identify the new nation Turkishness with the culture of Alevis (Massicard, 2017: 43). The Republican tradition, which ignores the diversity in the country, has tried to establish a nation-state ideology based on a common culture and language

4 "Suffering" has a deeper meaning for Alevi tradition. They figure a connection between good people and suffering, like Imam Hüseyin -Ali's son who was executed after torturing. Especially old women who come together at the activities like Ashura days, like comparing their health problems, lost and pain and telling how much they have been suffering. 
(Karakas, 2007: 276). As a result of this, historical theses and language theories were created that identify the nation with Turkish ethnicity, and the new regime invented "religious Muslims, Kurds, and minorities" at home as others who did not coincide with these theories (Karakas, 2006: 155). Alevis' attitude to this fiction was positive because of being Turk who was insulted by Ottomans before. Securing an agreement with the secular regime established after the collapse of the Ottoman Empire meant for Alevis to be a part of this fiction. In particular, the distance of the new regime to Islamist movements, which he described as reactionary, has been the most important factor convincing Alevis. For example, events such as the 1960 coup that occurred after the rise of Islamism suppressed by the Kemalist regime in the 1950s, or the February 28 Process $^{5}$, which ended the debate on the transition to an Islamist regime in the 1990s, did not cause any reaction in Alevis.

On the other hand, understanding the Alevi's antipathy towards the AKP (which arises from AKP's Ottomanist discourse) is also important to see its relations with nationalist discourse. The AKP stated that it struggled with nationalism in the first period of its rule and removed the phrase 'TC' (Turkish Republic) from the ministries' signs and ended the practice of reading the oath in schools. Moreover, the attempts to use the symbols of July 15 instead of Ataturk on the coins after the coup attempt have also pushed Alevis, who perceived these as attacks on the secular Republic of Atatürk, into the nationalist opposition.

"We should not forget that they are enemies of this Republic which was found by Atatürk, they want our children to forget our national oath cooperating with Kurdish" (interview n. 8, man, 32, worker, 23 December 2019)

The Alevis' approach to the AKP's solution process with the Kurds was also influenced by its antipathy towards the AKP. The fact that "the solution process" is being carried out with the AKP and in a non-transparent manner has fueled the feeling of distrust towards the Kurdish opposition. It has been difficult for the Alevis, who have adopted an understanding against violence - though not historically, but today- and affected by intense state propaganda, to accept the fact that the PKK, which it has seen as the internal enemy to date, was sitting at the table with the state. On the other hand, the Alevis were concerned that the AKP, which defined the extremist groups in Syria as 'angry Sunnis', aimed to become a leader in the Middle East and dreamed of a neo-Ottomanist state, has reached an agreement with the Kurds based on the understanding of the ummah.

"In 1516-1537 Sultan Kanuni Süleyman sent shaykh al-islam İdrisi Bitlis-i (a Kurdish religious leader) blank sealed firmans to massacre Alevis. How can I love Idrisi Bitlis-i or Saidi Nursi? They still represent Kurdish people's mentality. They are not lettered, they have Sikhs, they do whatever their Sikhs tell" (interview n. 23, man, 68, dede-Alevi's religious leader, 08.08.2020).

"When it is about ummah, most of Kurds can support AKP again. There are very extreme religious groups and cults in Kurds. When I was working in Van, I heard people saying that

528 February, which is known as "Postmodern coup", is name of a process which ends with overthrowing the coalition government. One of the parties of the coalition Refah Partisi (Wellfare Party) was associated with extremist Islamic communities and their activities were drawing reactions of the military. Just after the meeting of National Security Council (Milli Güvenlik Komitesi) on $28^{\text {th }}$ of February in 1997, the government had to resign. 
killing 7 Alevis is a way to go to heaven directly." (interview n. 28, woman, 35, teacher, 20 August 2020).

During the beginning of this "solution" period, Gezi Park events took place. The anti-AKP demonstrations started with a protest against disproportionate police violence against young people criticizing AKP's environmental policies and spread to the whole country within a few days. The claims that the Kurds did not support these demonstrations in order not to harm the solution process caused a significant opportunity to be missed such as the unification of the opposition. Since then it has been discussed at ashoura days, funerals at village associations ${ }^{6}$ of Alevis. While a few of them defend HDP's democratic targets, others claim that Alevis should not trust Kurds and they object to give support to HDP.

"When they have benefits Kurds can get along with even AKP. During the solution process they were walking around with their guns in front of our soldiers in cooperation with AKP. Our children died on the streets in Gezi Park events. Where were the Kurdish opponents then? The military were dismissing patriotic soldiers, they were arresting them by fabricating evidence. Erdogan said that he was the prosecuter of these trials. Kurdish Party watched them all." (Interview n. 7, Man, 48, craft, 20.12.2019).

Rising nationalism at a time when conflicts and wars deepened in the Middle East and three million Syrian refugees came to the country, has also influenced Alevis as anti-AKP rhetoric. Concerns over AKP allowing Islamist extremist groups to cross into Syria and economic support allegedly given to refugees who had to migrate to Turkey were met with reaction due to the economic crisis and unemployment problem.

The fact that Kurds were seeking new ways of democracy both in Syria and Turkey was blocking the AKP's expansionist goals, The HDP was not ratifying the Presidential System and increased its votes in the 2015 elections, and AKP ended the 'solution process' when it also could not get the votes it expected. The rapid transformation of the AKP's discourse has made the Kurds target again. With the AKP's decision to join the imperialist plans in Syria in cooperation with the US, the Kurds were again marginalized. This is important to make visible the international ties of nationalism at the national level. While Kurds were re-described as both internal and external enemies, their lives and living spaces were occupied and the renewed election was dominated by fear.

The Kurds, who drew reaction because the solution process could not be explained to the public well (or the AKP did not actually carry out the process in order to ensure peace), were turned them into enemies as 'terrorists who ditch trenches on the streets of cities'. In this way, the practices such as curfews in Diyarbakır, Mardin, and Şırnak have been legitimized and it was expected that the persecution against the Kurdish people will be tolerated while the cities are destroyed. This effort to create perception has been accepted throughout society. Every action that breaks the silence by recalling the most basic democratic rights were suppressed by the overreaction of the state institutions and the increasingly authoritarian regime tried to cover its crisis with nationalist rhetoric. ${ }^{7}$

\footnotetext{
${ }^{6}$ These associations are the main social networks of Alevis who came from their villages to Ankara quite a while ago and their children who grow up here. They meet with their relatives in these places for funerals, memorials, religious practices etc.

${ }^{7}$ Today, the AKP continues to enforce a hostile law that is defined as 'civil death', not only for those who raised their voices in the Kurdish issue, but also for the entire opposition after the Cemaat's 2016 coup attempt. The passports of these people,
} 


\section{Criticism of Nationalism as an Ideology and Identity Construction}

Nationalism theories seek answers to the question of how nationalist rhetoric influences peoples. Perspectives that replace nationalist approaches and treat nationalism as a fiction pave the way for understanding how nationalism is rebuilt in different periods. In the famous phrase of Benedict Anderson (1995: 20,21), the nation is an "imagined political community" and is designed as "a deep and horizontal companionship", regardless of the level of inequality and exploitation. Anderson thinks that the imagination of the new community is the output of modernization and capitalism. It is like the perception of the 'common language' created by printing houses that print for the market in languages other than Latin. Questioning the idea of a nation of the modernist paradigm with the notion of ethnicity, Anthony Smith (1994) points to the way in which an ethnic group is chosen and transformed into a nation. Smith's ethnosymbolist approach to nationalism is important to understand the first construction of nationality, in which Alevis also had the sense of belonging. Smith (1994: 163, 164), showing Turkey as an example for his theory, argues that this construction is based on Pan-Turkism, in which the Arabs and non-Turks were alienated during the Tanzimat Period. Accordingly, it is stated that the Republic of Atatürk takes this potential, which was taken over by the soldiers, as the basis of secular, Westernist nationalism. Subsequently, non-Anatolian irredentism was clipped, Ottomanism and Islamism were rejected and the idea of Turkishness originating from Central Asia was tried to be invented with ethnic myths, values and symbols. This story must have resulted with an easier adoption of Alevis, who embrace Middle Asian traditions, to the new Kemalist regime.

According to Michael Billig (2002: 49), nationalism makes people forget that their world was built historically. Billig defines nationalism as an ideology that makes nations appear to be the natural state of the world (as if a world without nations is not possible). Michael Billig's approach provides important observation areas, especially in terms of seeing how Alevis interpret the recent developments. Billig (2002: 55) states that "banal nationalism" has become a custom with objects with national symbols such as flags and coins. Following Billig, Özkırımlı (2008: 247-250) emphasizes that tools such as flags, which are often not even noticeable, and habits imposed on daily life are examples of "banal nationalism" that prepare the rise of nationalism in times of crisis. He says that our identity is constantly determined by the politicians especially speaking to the nation and speaking on behalf of the nation and it enables us to perceive our country as "a natural environment."

Understanding how this discourse influences Alevis requires understanding the construction of Alevis' identity which does not exist without an 'other'. Stuart Hall (1996), who says that what determines who we are is primarily "who we are not", sees identity as an incomplete process of interaction. This fiction based on being different does not need rational foundations. Barth (2001: 18) emphasizes the differences identified by social interaction rather than objective differences in the construction of ethnic identity. From this point of view, the context in which this perception of otherness emerged / selected and how it was articulated into its own narratives of identity and how this narrative was influenced by the changing conditions also awaits

whose social and economic rights were taken away, were confiscated and these people were sentenced "to eat tree roots". The State of Emergency State, in which the most basic human rights were suspended, was said to have been implemented in France (after the ISIS attacks in Paris) as well. The AKP has repeatedly referred to this as an example to suppress its secular opponents who have not abandoned their goal of Westernization and EU membership. The authoritarianization process, which promotes hatred against democratic demands, provides legitimacy with the idea of nationalism and the superiority of national interests. 
clarification. Thus, it will be possible to find the traces of the dynamics constituting the Alevi identity at the points where the ideology of nationalism "calls out" (Althusser, 2002).

However, although this study starts from the example of conflicting identities, it has to clarify the problems that cannot be reduced to the question of "identity" only at a time when capitalism rises authoritatively. Stuart Hall, one of the most important names of identity studies, stated that concepts such as race are located in a series of social and economic relations and expressed his discomfort with the reduction of the idea that the race is purely cultural and ideological (Solomos, 2018: 24). Of course, the construction of identity provides us with meaningful cultural stories for each period. However, these fictions and oppositional positions often act to cover up an economic conflict. The increasing Alevi-Sunni conflict in the 1970s accelerated the process of chaos that enabled the military coup. Class opposition groups in the society were almost destroyed after the military coup and changes which engaged Turkey to neoliberalism became possible. Alevi survivors mostly left the city, after the Maraş Massacre ${ }^{8}$ that took place in the 1970s with the participation of Sunni neighbors who were annoyed by Alevis, who became rich with populist agricultural policies and started to become property owners in the cities. The ruling class, which are strengthened by categories such as race and sect can see every option as acceptable in order not to lose its social and economic privileges.

Today, the economic aid that is claimed to be provided to Syrian immigrates does not lead people to question the conjuncture that caused the migration of Syrians, on the contrary, it escalates Turkish nationalism. Just like this, especially in times of economic crisis, it is seen that the hostility against the Kurdish people has increased.

"He (Kurdish man) has a regular government grant, he does not cultivate his field, he has a dozen of children, he spends his time in coffeehouses till the evening and he says he is a victim. I am the victim, I have to work all day under stress although I am retired" (interview n. 5, man, 66, chauffeur, 04.10.2019).

Economic infrastructure of the fiction brings Alevis closer to Turkish nationalism. On the one hand, the imperialist strife that destroyed Syria has put the agenda and economic and democratic demands of the people in the second place with the existence of war. On the other hand, instead of considering the real source of the problems such as refugee migration and economic crisis, it updates the categories of internal and external enemies and makes reflexive thinking dominant. This situation causes peoples to feel hostility towards each other.

The critique of nationalism and identity, which is carried out in parallel with economic developments, will also give us an opportunity to see how the rising nationalism discourse in the world affects and dissipates different social opposition groups under an authoritarian rule. As Massicard (2017: 76) emphasized, every identity-based movement creates new little identities like Alevis who can not come together for their benefits. However, as stated, if Alevis and Kurds can establish a symmetrical relationship, and can draw a common path in their demands for equal citizenship, a true democracy can emerge in Turkey. There is a hope we saw at the last election in 2019 which could bring democratic people together against authoritativeness. Especially young and educated Alevis are open for questioning some prejudgments.

\footnotetext{
${ }^{8}$ The research and evaluation in 2012 shared by the former HDP deputy Sirrı Süreyya Önder, who also witnessed the period is important. https://www.dailymotion.com/video/xw8uv4, 27.07.2018.
} 
"Kurdish opponents should move away nationalist discourse and focus on the main problems of the society like how Selahattin Demirtas did. I trust Kurdish opposition and find it very necessary unless some Alevis. But I think this distrust is changing with the manner of HDP" (interview n. 18, man, 32, engineer, 03.08.2020).

"I support Kurdish opposition. But in non-Kurdish society of Alevis have a strong prejudge against Kurdish people because of Kemalist and state centered view. It is very hard to overcome this bias unfortunately" (interview n. 17, man, 23, student, 02.08.2020).

\section{References}

Althusser, Louis (2002), Ideoloji ve Devletin Ideolojik Aygitları, trans: Yusuf Alp, Mahmut Özışı, İstanbul: İletişim, 5. ed.

Anderson, Benedict (1995), Hayali Cemaatler, trans: İskender Savaşır, İstanbul: Metis, 2. ed.

Aydın, Suavi (2016), "Bir Etnodinsel Kimlik Olarak Alevilik", in: Kızılbaşlık Alevilik Bektaşilik, der: Yalçın Çakmak, İmran Gürtaş, İstanbul: İletişim, 2. ed, s. 11-32.

Balibar E., Wallerstein I. (2007), Irk Ulus Sinıf, trans: Nazlı Ökten, İstanbul: Metis, 4. ed.

Ballı, Remzi (1992), Kürt Dosyası, İstanbul: Cem.

Barth, Fredrik (2001), Etnik Gruplar ve Sintrlart, trans: Ayhan Kaya, Seda Gürkan, İstanbul: Bağlam Yayıncılık

Billig, Michael (2002), Banal Milliyetçilik, trans: Cem Şişkolar, İstanbul: Gelenek.

Bruinessen, Martin Van (2013), Kürtlük Türklük Alevilik, trans: Hakan Yurdakul, İstanbul: İletişim, 10. ed.

Freeden, Michael (2011), İdeoloji, trans: Hakan Gür, Ankara: Dost.

Hall, Stuart (1996), Questions of Cultural Identity, ed. by. Stuart Hall and Paul du Gay, Sage Pub.

Karakaş, Mehmet (2006), Küreselleşme ve Türk Kimliği, Ankara: Elips.

Kirişçi, Kemal; Winrow, Gareth (1997), Kürt Sorunu, Kökeni ve Gelişimi. trans: Ahmet Fethi, İstanbul: Tarih Vakfı Yurt Yayınları.

Massicard, Elise (2017), Türkiye'den Avrupa'ya Alevi Hareketinin Siyasallaşması, çev: Ali Berktay, İstanbul: İletişim, 3. Ed.

Melikoff, Irene (1994), Uyur İdik Uyardılar: Alevilik-Bektaşilik Araştırmaları, trans: Turan Alptekin, İstanbul: Cem Yayınları.

Ranciere, Jacques (2015), Demokrasi Nefreti, trans: Utku Özmakas, İstanbul: İletişim

Smith, Anthony (1994), Milli Kimlik, trans: Bahadır Sina Şeker, İstanbul: İletişim

Solomos John (2018), "Stuart Hall: Irk Sınıf ve Kimliğin Eklemlenişleri”, Duvar 35, NisanMayıs 2018, trans: E. Arıkan, U. Özmakas, s. 23-28.

Sözen, Yunus (2011), “AKP ve bir Otoriterleşme İdeolojisi Olarak Neo-Muhafazakâr Popülizm”, Yeniyol, 43, Ekim 2011, s. 7-23. 
Thompson, John B. (1990), Ideology and Modern Culture: Critical Social Theory in the Era of Mass Communication, USA: Standford University Press.

Van Dijk, Teun (2003), “Söylem ve İdeoloji Çok Alanlı Bir Yaklaşım”, in: Söylem ve İdeoloji Mitoloji Din İdeoloji, ed: Barış Çoban, Zeynep Özarslan, İstanbul: Su Yayınları.

Yıldırım, Rıza (2018), Aleviliğin Doğuşu (The Origins of the Qizilbash Identity in Anatolia), trns: Barış Yıldırım, İstanbul: İletişim, $2^{\text {nd }}$ ed.

Y1lmaz, Nail (2005), Kentin Alevileri, İstanbul: Kitabevi.

Zırh, Besim Can (2016), "Bir Kesişim Kümesi Olarak Milli-Muhafazakârlığın Üç Değili: Aleviler, Ermeniler, Kürtler”, in Klzılbaşlık Alevilik Bektaşilik, ed: Yalçın Çakmak, İmran Gürtaş, İstanbul: İletişim, 2. ed., 327-365. 